\title{
TERAPI AKTIVITAS KELOMPOK PENYALURAN ENERGI : SENAM POCO-POCO MENURUNKAN GEJALA PERILAKU KEKERASAN PADA PASIEN SKIZOFRENIA
}

\author{
Desak Made Ari Dwi Jayanti ${ }^{1}$, Nyoman Nana Antari ${ }^{2}$ \\ ${ }^{1,2}$ STIKes Wira Medika Bali
}

\begin{abstract}
ABSTRAK
Pendahuluan : Perilaku kekerasan merupakan permasalahan yang sering terjadi pada pasien skizofrenia dimana dapat melukai atau menciderai diri sendiri atau orang lain. Penanganan perilaku kekerasan dilakukan dengan memberikan intervensi psikososial seperti terapi aktivitas kelompok penyaluran energi. Salah satu aktivitas yang dapat diberikan untuk mengurangi perilaku kekerasan adalah melalui aktivitas fisik berupa tari dan gerak yang digabungkan dengan musik yaitu senam poco-poco. Tujuan penelitian ini mengetahui terapi aktivitas kelompok penyaluran energi : senam poco-poco menurunkan gejala perilaku kekerasan pada pasien skizofrenia. Metode : Pra eksperimental dengan rancangan One-group pre-post test design. Tekhnik sampel menggunakan Purposive sampling dengan jumlah sampel 22 orang. Alat ukur berupa lembar obervasi gejala perilaku kekerasan. Hasil : Hasil penelitian menunjukkan rerata risiko perilaku kekerasan pre test sebesar 13,77 termasuk risiko perilaku kekerasan sedang dan hasil post test sebesar 5,64 termasuk risiko perilaku kekerasan ringan. Hasil uji statistik Paired $t$ Test diperoleh nilai $\mathrm{p}<0,05$ menunjukkan terapi aktivitas kelompok penyaluran energi : senam pocopoco menurunkan risiko perilaku kekerasan pada pasien skizofrenia. Disarankan agar pasien dengan skizofrenia diberikan pelatihan senam poco-poco secara berkelanjutan.
\end{abstract}

Kata Kunci : Senam Poco - Poco, Perilaku Kekerasan, Skizofrenia

\section{GROUP ACTIVITY ENERGY DISTRIBUSY THERAPY : POCO - POCO GYMNASTICS DECREASE SYMPTOMS OF VIOLENCE BEHAVIOR IN SCHIZOPHERIC CLIENT}

\begin{abstract}
Introduction: The main problem that often occurs in schizophrenia patient is violent behavior when can get injure yourself or others. The handling of violent behavior is carried out with a combination of psychopharmacology and psychosocial interventions such as the therapy of channeling group activity. One activity that can be given to reduce violent behavior is through physical activity in the form of dance and motion that is combined with the music of poco-poco gymnastics. The purpose of this study is group activity energy distribusy therapy: poco-poco exercise, decrease symtom of violent behavior on schizophrenic patient. Methods : Type of pre experimental study, using Onegroup pre-post test design. Sample technique used Purposive sampling with 22 samples. Data collection using observation sheets.Result : The results showed that the risk of pretest risk behavior was 13.77, including the risk of moderate hardness behavior and post test results of 5.64, including the risk of mild violent behavior. Paired t Test statistic test results obtained $p<0.05$ indicates there is group energy distribution therapy activities: poco-poco exercises can decrease symtom of violent behavior in schizophrenic patients. recommended for patients with schizophrenia to be given continuous poco-poco TAK training.
\end{abstract}

Keywords: Poco - Poco Gymnastic, Violent Behavior, Schizophrenic 


\section{PENDAHULUAN}

Berbagai gejala yang sering terjadi pada pasien skizofrenia terutama adalah perilaku kekerasan sehingga masyarakat menganggap bahwa orang yang mengalami skizofrenia identik dengan perilaku kekerasan. Masyarakat juga menganggap bahwa pasien skizofrenia berbahaya sehingga tidak mau mendekati pasien skizofrenia yang pernah melakukan tindakan perilaku kekerasan ${ }^{1}$. Perilaku kekerasan merupakan salah satu gejala yang biasa terjadi sehingga keluarga baru membawa pasien untuk berobat ke rumah sakit ${ }^{2}$.

World Health Organization (WHO) menyatakan bahwa jumlah pasien gangguan jiwa cukup tinggi hingga mencapai 450 juta orang diseluruh dunia pada tahun 2013. Hasil Riset Kesehatan Dasar 2013 menunjukkan Indonesia memiliki prevalensi gangguan jiwa berat sebesar 1,7 per mil meningkat dibandingkan hasil Riskesdas 2012 sebesar 1, 4 per mil. Beberapa daerah dengan gangguan jiwa berat terbanyak ada di Daerah Istimewa Yogyakarta, Aceh, Sulawesi Selatan, Jawa Tengah dan Bali menempati urutan ke tiga dengan prevalensi sebesar 2,3 per mil ${ }^{3}$.

Skizofrenia merupakan masalah utama gangguan jiwa di dunia, sebagian besar pasien yang masuk rumah sakit jiwa mengalami skizofrenia $(85 \%$ dengan skizofrenia ) yang memerlukan rawat inap dan jalan cukup lama ${ }^{4}$. Berbagai tanda dan gejala yang muncul pada pasien skizofrenia seperti perilaku disorganisasi bicara kacau dan perilaku katatonik seperti keadaan gaduh gelisah, delusi, halusinasi, kekacauan kognitif, dijadikan dasar profesi keperawatan dalam menegakkan diagnosis keperawatan ${ }^{2}$.

Pasien dengan perilaku kekerasan menunjukkan gejala yang kurang bersahabat, antara lain membentak, muka tegang dan wajah tegang, mata melotot, intonasi suara tinggi, mengamuk, memukul benda-benda di sekitarnya hingga tindakan-tindakan yang dapat mengancam keselamatannya sendiri bahkan keselamatan orang lain seperti menyerang orang-orang disekitarnya termasuk dokter dan perawat $^{5}$. Perilaku kekerasan yang dilakukan pasien dapat menyebabkan cidera pada diri sendiri maupun orang lain, sampai kematian ${ }^{6}$. Penelitian terkait pada 61 responden di RSJ Tampan Pekan Baru menunjukkan adanya tindakan perilaku kekerasan pada perawat berupa ancaman fisik sebesar $79 \%$, penghinaan sebesar $77 \%$ dan kekerasan verbal sebesar $70 \%$. Responden yang melaporkan mengalami kekerasan fisik yang berakibat cedera ringan sebesar 51\% dan pernah mengalami kekerasan fisik yang menyebabkan cedera serius sebesar $20 \%^{7}$

Diperkirakan tidak lebih dari $10 \%$ klien skizofrenia dengan perilaku kekerasan mengalami penurunan gejala hanya dengan pendekatan terapi antipsikotik, dan sejumlah $90 \%$ membutuhkan berbagai pendekatan dinamis termasuk farmakoterapi, , terapi keluarga, terapi individu, terapi perilaku dan terapi kelompok dengan terapi aktivitas kelompok $(\mathrm{TAK})^{8}$.

Salah satu penatalaksanaan perilaku kekerasan melalui pendekatan kelompok adalah terapi aktivitas kelompok penyaluran energi yang merupakan teknik untuk menyalurkan energi secara kontruktif dan asertif dengan mengungkapkan marah tanpa menimbulkan kerugian pada diri sendiri maupun lingkungan ${ }^{9}$. Aktivitas yang digunakan dalam aktivitas kelompok penyaluran energi adalah dengan aktivitas fisik yang dapat memperlancar peredaran darah otak, meningkatkan jumlah dopamin dan serootonin yang dapat menimbulkan perasaan senang, rasa puas dan suasana hati yang nyaman ${ }^{10}$.

Salah satu aktivitas yang dapat diberikan kepada pasien skizofrenia untuk mengurangi perilaku kekerasan adalah melalui aktivitas fisik berupa tari dan gerak yang digabungkan dengan musik yaitu senam poco-poco yang 
merupakan senam yang diiringi oleh lagu daerah Madado dengan gerakan yang sederhana sehingga akan mudah diikuti oleh pasien dengan musik yang menyenangkan sehingga akan menarik untuk pasien ${ }^{11}$.

Latihan fisik melalui senam pocopoco dapat memperlancar aliran darah ke otak yang dapat merangsang pelepasan zat kimia ,Gamma Amino Butyic Acid (GABA) dan beta endorphin yang dapat mengurangi rasa tertekan, cemas dan stress,suasana hati menjadi lebih baik dan mencegah kemarahan $^{12}$. Selain itu juga dapat memperbaiki dan meningkatkan kondisi dan fungsi dari sistem peredaran darah jantung, susunan saraf, pernafasan, pencernaan, endokrin, dan sistem biomotorik. Secara mental dapat meningkatkan konsentrasi dan menjaga kestabilan penguasaan diri, mengurangi atau menghilangkan perilaku kekerasan, stress dan ketegangan ${ }^{13}$.

Berdasarkan data dari Bidang Keperawatan di Rumah Sakit Jiwa Provinsi Bali, didapatkan data pasien dengan diagnosa perilaku kekerasan tahun 2015 sebanyak 923 orang, kemudian tahun 2016 meningkat menjadi 1120 orang dan tahun 2017 pasien yang dirawat dengan riwayat perilaku kekerasan sebanyak 1236 orang. Rata-rata pasien yang dirawat dengan risiko perilaku kekerasan dalam tiga bulan terakhir yaitu bulan Desember 2017-Pebruari 2018 sebanyak 112 orang, sedangkan jumlah rata-rata jumlah pasien yang dirawat dengan masalah risiko perilaku kekerasan pada bulan Desember 2017Pebruari 2018 yaitu : Ruang Bratasena (Intensif) : 20 orang, Ruang Drupadi : 12 orang, Ruang Kunti : 11 orang, Ruang Rsi Bisma: 13 orang, Ruang Abimanyu : 15 orang, Ruang Arimbi : 16 orang, Ruang Darmawangsa : 2 orang, Ruang Nakula : 13 orang dan Ruang Sahadewa : 10 orang $^{14}$.

Penatalaksanaan klien dengan risiko perilaku kekerasan di ruang rawat inap RSJ Provinsi Bali dilakukan dengan terapi antipsikotik, terapi individu melalui penerapan strategi pelaksanaan (SP) perilaku kekerasan seperti relaksasi nafas dalam, memukul bantal/kasur, cara verbal serta spiritual, terapi aktivitas kelompok stimulasi persepsi dan terapi musik. Berdasarkan data yang diperoleh tentang perubahan gejala klien risiko perilaku kekerasan setelah diberikan penanganan didapatkan data dari 112 klien risiko perilaku kekerasan sebanyak 60 orang $(53,57 \%)$ belum mengalami perubahan gejala perilaku kekerasan setelah diberikan terapi antipsikotik berupa pemberian obat-obat psikofarmaka, terapi individu, terapi aktivitas kelompok stimulasi persepsi dan terapi musik seperti musik tradisional dan lagu-lagu. Berdasarkan data tersebut diperlukan upaya lain untuk penanganan klien risiko perilaku kekerasan sehingga dapat mencegah akibat yang ditimbulkan.

Berdasarkan uraian diatas penulis sangat tertarik untuk mengetahui lebih mendalam tentang "pengaruh terapi aktivitas kelompok penyaluran energi : senam poco-poco terhadap risiko perilaku kekerasan pada klien skizofrenia di Rumah Sakit Jiwa Provinsi Bali”.

\section{METODE}

Jenis penelitian ini adalah Pra Experiment One-group Pra-testposttest Design yang bertempat di Rumah Sakit Jiwa Provinsi Bali pada tanggal 3 Mei - 16 Juni 2018. Sampel sesuai kriteria inklusi sebanyak 22 orang, dengan tekhnik Purposive Sampling. Variabel independen terapi aktivitas kelompok penyaluran energi : senam poco-poco. Variabel dependen risiko perilaku kekerasan pasien skizofrenia.

Analisis data pada penelitian ini mengunakan uji "Paired $t$ Test". Penentuan hipotesis diterima apabila nilai signifikansi $(\mathrm{p}<0,05)$ maka terapi aktivitas kelompok penyaluran energi : senam poco-poco menurunkan gejala 
perilaku kekerasan pada pasien skizofrenia.

\section{HASIL}

\section{Karakteristik Subyek Penelitian}

1. Karakteristik responden berdasarkan umur

\begin{tabular}{cccc}
\hline \multirow{2}{*}{ No } & Umur & \multicolumn{2}{c}{ Hasil } \\
\cline { 3 - 4 } & & $\mathrm{F}$ & $\%$ \\
\hline 1 & $\begin{array}{l}18-25 \\
\text { tahun }\end{array}$ & 4 & 18.2 \\
\hline 2 & $\begin{array}{l}26-35 \\
\text { tahun }\end{array}$ & 3 & 13.6 \\
\hline 3 & $\begin{array}{l}36-45 \\
\text { tahun }\end{array}$ & 15 & 68.2 \\
\hline & Total & 22 & 100.0 \\
\hline
\end{tabular}

Berdasarkan Tabel diatas menunjukkan karakteristik responden berdasarkan umur sejumlah 15 orang $(68,2 \%)$ berumur $36-45$ tahun

2. Karakteristik responden berdasarkan pendidikan

\begin{tabular}{cccc}
\hline No & $\begin{array}{c}\text { Pendidika } \\
\mathrm{n}\end{array}$ & \multicolumn{2}{c}{ Hasil } \\
\hline 1 & $\begin{array}{c}\text { tidak } \\
\text { sekolah }\end{array}$ & 9 & $\%$ \\
\hline 2 & SD & 7 & 31.8 \\
\hline 3 & SMP & 6 & 27.3 \\
\hline & Total & 22 & 100,0 \\
\hline
\end{tabular}

Berdasarkan Tabel diatas menunjukkan karakteristik responden berdasarkan pendidikan sebanyak 9 orang $(40,9 \%)$ tidak sekolah.

3. Karakteristik responden berdasarkan pekerjaan

\begin{tabular}{cccc}
\hline $\mathrm{N}$ & \multirow{2}{*}{ Pekerjaan } & \multicolumn{2}{c}{ Hasil } \\
\cline { 3 - 4 } $\mathrm{o}$ & & $\mathrm{F}$ & $\%$ \\
\hline 1 & Tidak & 17 & 77.3 \\
\hline 2 & Swasta & 5 & 22.7 \\
\hline & Total & 22 & 100,0 \\
\hline
\end{tabular}

Berdasarkan Tabel diatas menunjukkan karakteristik responden berdasarkan pekerjaan sebanyak 17 orang $(77,3 \%)$ tidak bekerja.
Hasil Analisis

\begin{tabular}{|c|c|c|c|c|c|}
\hline Variabel & $\mathrm{n}$ Rerata & SB & $\begin{array}{l}\text { Selisih } \\
\text { Rerata }\end{array}$ & $\mathrm{p}$ & $\mathrm{t}$ \\
\hline $\begin{array}{l}\text { Risiko } \\
\text { Perilaku } \\
\text { Kekerasan } \\
\text { Pre Test }\end{array}$ & 2213,77 & 1,998 & & & \\
\hline $\begin{array}{l}\text { Risiko } \\
\text { Perilaku } \\
\text { Kekerasan } \\
\text { Post Test }\end{array}$ & $22 \quad 5,64$ & 1,56 & 8,136 & 0,00 & 28,91 \\
\hline
\end{tabular}

Berdasarkan Tabel diatas menunjukkan rerata risiko perilaku kekerasan Pre Test 13,77 kategori sedang. Rerata risiko perilaku kekerasan post test 5,64 kategori ringan. Hasil uji dengan Paired $t$ Test diperoleh nilai $\mathrm{t}_{\text {hitung }}=28,911>\mathrm{t}$ tabel $\mathrm{df} 21=$ 1,721 dan $\mathrm{p}$ value $=0,000<\alpha 0,05$ artinya ada perbedaan yang bermakna risiko perilaku kekerasan pada klien skizofrenia pre-test dan post-test hal ini menunjukkan ada pengaruh terapi aktivitas kelompok penyaluran energi : senam poco-poco terhadap risiko perilaku kekerasan pada pasien skizofrenia di Rumah Sakit Jiwa Provinsi Bali serta terjadi penurunan rerata risiko perilaku kekerasan antara pre test dengan post test sebesar 8,136.

\section{PEMBAHASAN}

1. Risiko perilaku kekerasan pada pasien skizofrenia sebelum diberikan terapi aktivitas kelompok penyaluran energi : senam pocopoco

Rerata nilai pre-test pada pasien skizofrenia sebesar 13,77 dengan kategori sedang. Hal ini sesuai dengan hasil observasi tanda fisik semua responden pandangannya tampak tajam, tanda emosional sebagian besar suaranya keras dan suka memaksa milik pasien lain, dari tanda kognitif sebagian besar suka mengancam secara verbal dan suka berdebat, tanda sosial seluruh pasien suka mengertak dan dari perilaku seluruhnya sering mondar-mandir dalam ruangan. Gejala-gejala tersebut 
sesuai dengan teori dimana risiko perilaku kekerasan kategori sedang menunjukkan gejala fisik dan verbal, yang masih terkontrol dimana belum melakukan tindakan perilaku kekerasan yang aktual hanya berupa tanda dan gejalanya saja ${ }^{4}$. Menurut Yosep (2016) resiko perilaku kekerasan adalah adanya kemungkinan seseorang melakukan tindakan dalam bentuk destruktif dan masih terkontrol ${ }^{2}$.

Teori lain mengatakan Perilaku kekerasan menggambarkan perasaan tidak aman, ekspresi tegang, mondar mandir dan menunjukkan gejala-gejala ketergantungan dan perlunya perhatian orang lain 6 .

Hasil penelitian yang didapat didukung oleh teori (Yosep, 2016) risiko perilaku kekerasan merupakan respon maladaptif dari marah. Kemarahan memang merupakan suatu respon yang normal, agresi akan terjadi jika rasa marah diungkapkan dengan cara yang salah. Kemarahan yang tidak mampu diungkapkan secara asertif atau baik akan menyebabkan respon yang paling maladaptif yaitu perilaku kekerasan ${ }^{2}$.

Hasil penelitian didukung oleh penelitian yang dilakukan Ekawati (2013), bahwa sebesar 73,3\% (11 orang) melakukan perilaku agresif dengan kategori sedang ${ }^{1}$. Sodikin dkk (2015) menunjukkant bahwa skor gejala perilaku kekerasan sebesar 58 yang artinya responden pada kelompok kontrol dan perlakuan dalam kondisi akut / intensif (skor Modified Global Assesment of Function-Revised $($ mGAF-R $)<30^{15}$

Dihubungkan dengan usia sebanyak 15 orang $(50 \%)$ berumur 3655 tahun, hal ini menunjukkan kondisi fisikdi pengaruhi usia,bertambahnya usiamaka akan menurun pula kondisi fisik sehingga bertambah pula stresor yang dihadapi, kondisi seperti ini akan menyebankan seseorang rentan mengalami gangguan jiwa.

Dilihat dari segi pendidikan sebagian besar yaitu sebanyak 9 orang $(40,9 \%)$ tidak tamat SD. Peneliti berpendapat pendidikan mempengaruhi perkembangan kepribadian seseorang, bahwa pada umumnya pendidikan itu meningkatkan kemampuan intelegensi mampu beradaptasi dengan lingkungan dan memiliki ketrampilan koping yang lebih baik untuk menghadapi stressor dari pada orang yang berpendidikan rendah. Tingkat pendidikan seseorang akan mempengaruhi, pola pikir, kepribadian dan perilaku seseorang. Semakin tinggi pendidikan formal, maka perilaku individu diharapkan lebih mudah dalam mengadopsi pengetahuan baru dan mempunyai kepribadian serta perilaku yang baik.

Karakteristik responden berdasarkan pekerjaan sebagian besar tidak bekerja. Menurut peneliti, sebagian besar responden tidak bekerja selain disebabkan karena persaingan dalam mencari pekerjaan yang sangat berat dimana tidak hanya membutuhkan prestasi dan kompetensi tetapi ada halhal lain yang mempengaruhi seseorang bisa mendapat pekerjaan seperti relasi dan uang. Seseorang yang pintar atau terampil tidak menjadi jaminan cepat mendapat pekerjaan, sehingga kegagalan dalan mencari pekerjaan apalagi kegagalan yang berulang dapat menjadi pencetus seeorang mengalami gangguan jiwa. Hasil penelitian ini menunjukkan bahwa perilaku kekerasan pada pasien skizofrenia termasuk perilaku kekerasan kategori sedang, menurut pendapat peneliti dapat disebabkan karena kurangnya kemampuan pasien dalam menghadapi ancaman dan mengenal tentang gejala perilaku kekerasan. Pasien mengungkapkannya dengan rasa bermusuhan dan berkata kasar.

2. Risiko perilaku kekerasan pada pasien skizofrenia setelah diberikan terapi aktivitas kelompok penyaluran energi : senam poco-poco

Hasil penelitian menunjukkan rerata risiko perilaku kekerasan post-test sebesar 5,64 termasuk risiko perilaku kekerasan ringan. Hasil penelitian ini menunjukkan terjadi penurunan gejala 
risiko perilaku kekerasan dapat disebabkan karena pemberian aktivitas fisik berupa senam poco-poco, sebagai bentuk penyaluran energi bagi pasien. Hasil penelitian yang didapat didukung oleh teori Sujono, (2009) salah satu penatalaksanaan perilaku kekerasan melalui aktivitas fisik untuk penyaluran energi secara kontruktif dimana memungkinkan pengembangan polapola penyaluran energi seperti katarsis, peluapan marah dan rasa batin secara konstruktif dengan tanpa menimbulkan kerugian pada diri sendiri maupun lingkungan ${ }^{9}$.

Hal ini sesuai dengan teori Heryati (2014) aktivitas fisik melalui aktivitas fisik berupa tari dan gerak dapat merangsang pengeluaran hormon serotonin dan norepinefrin didalam otak termasuk sistim limbik yang berkaitan dengan pengendalian emosi, motivasi dan perasaan ${ }^{10}$.

Hasil penelitian ini sesuai dengan hasil penelitian Kirana (2014) menunjukan adanya peningkatan aggression self-control pada pasien dengan risiko perilaku kekerasan setelah diberikan senam aerobick low impact $^{16}$

Pelaksanaan senam poco-poco memberikan perasaan senang terhadap pasien, hal ini terlihat saat pasien mengikuti senam tampak tertawa-tawa dan bersemangat mengikuti gerakan sambil sesekali berinteraksi dengan temannya, pada minggu pertama pelaksanaan senam, pasien belum bisa teratur mengikuti gerakan yang diarahkan tetapi perlahan-lahan dengan dibimbing pasien mulai hafal gerakangerakan senam poco. Semua pasien tampak antusias mengikuti senam yang diberikan hal itu dibuktikan pasien meminta setiap hari senam dan sudah menunggu untuk mengikuti senam saat jadwal pelaksanaan senam. Karim (2014) mengatakan melakukan aktifitas fisik berupa senam dapat memperbaiki dan meningkatkan mood sehingga akan merasa lebih baik dan bugar ${ }^{17}$.
3. Pengaruh
Terapi
Kelompok Penyaluran
Aktivitas
Energi :

Senam Poco-Poco Terhadap Risiko Perilaku Kekerasan Pada Pasien Skizofrenia

Hasil penelitian menunjukkan terjadi penurunan rerata risiko perilaku sebesar 8,136. Nilai $\mathrm{p}<0,05$ artinya ada perbedaan hal ini menunjukkan terapi aktivitas kelompok penyaluran energi : senam poco-poco menurunkan gejala perilaku kekerasan. Menurut Lilik (2011) penatalaksanaan perilaku kekerasan melalui pendekatan kelompok adalah terapi aktivitas kelompok penyaluran energi. Aktivitas yang digunakan berupa tari dan gerak, dimana tujuan melakukan tari dan gerak tersebut adalah untuk menyalurkan energi pasien ${ }^{18}$.

Menurut Kuntaraf (2015) aktivitas fisik berupa senam poco-poco memberikan kegiatan positif bagi pasien, sehingga pasien mampu berfokus pada masalah yang dihadapi pasien saat ini, menciptakan suasana rileks, aman, dan menyenangkan sehingga merangsang pelepasan zat kimia Gamma Amino Butyic Acid (GABA), enkefallin, atau beta endorphin yang dapat mengeleminasi neurotransmiter rasa tertekan, cemas, dan stres sehingga menciptakan ketenangan dan memperbaiki suasana hati (mood) sehingga pasien tidak menunjukkan gejala risiko perilaku kekerasan $^{12}$.

Hasil penelitian ini sesuai dengan hasil penelitian Akhmad (2014) menunjukkan senam aerobic low impact berpengaruh terhadap skor agression self-control pada pasien dengan risiko perilaku kekerasan dengan nilai $\mathrm{p}=0,000^{19}$. Penelitian yang dilakukan Purniasari (2013) didapatkan ada pengaruh terapi musik relaksasi Rindik terhadap kemampuan mengontrol perilaku kekerasan pasien ${ }^{20}$. Penelitian terkait menunjukkan dengan melkukan aktifitas fisik berupa senam zumba pada pasien skizofrenia dapat meningkatkan kesehatan mentalnya dimana akan terjadi penurunan dari gejala-gejala perilaku pada pasien 
skizofrenia dimana salah satunya dapat mengurangi perilaku kekerasan ${ }^{21}$.

Menurut peneliti pemberian senam poco-poco memberikan kegiatan bermanfaat bagi pasien dan menyenangkan sehingga bermanfaat mengubah pola berpikir, perasaan dan perilaku pasien dalam kemampuan adaptasinya terhadap stresor. Pasien yang memiliki kemampuan beradaptasi dengan baik terhadap kejadian yang tidak menyenangkan akan mampu menunjukkan perilaku yang konstruktif.. Pasien juga dapat berinteraksi dengan pasien yang lain sehingga meningkatkan kemampuan sosialisasinya, rasa percaya diri, kemampuan ekspresi diri dan rasa empati.

\section{SIMPULAN DAN SARAN Simpulan}

Rerata resiko perilaku kekerasan sebelum diberikan senam poco-poco sebesar 13,77 dan setelah diberikan senam poco-poco 5,64 . Hasil analisis menunjukkan nilai $\mathrm{p}<0,05$ artinya terapi aktivitas kelompok penyaluran energi : senam poco-poco menurunkan gejala perilaku kekerasan pada pasien skizofrenia.

\section{Saran}

1. Kepada Rumah Sakit Jiwa Provinsi Bali

1) Diharapkan terapi aktivitas kelompok penyaluran energi : senam poco-poco dapat dilanjutkan secara rutin dan dibuatkan jadwal serta diharapkan tidak hanya diberikan kepada pasien resiko perilaku kekerasan tetapi dapat diberikan pada pasien dengan masalah keperawatan yang lain

2) Hasil penelitian ini bisa digunakan sebagai acuan dalam penyusunan SOP terapi aktivitas kelompok penyaluran energi senam poco-poco pada pasien skizofrenia secara umum dan pasien risiko perilaku kekerasan
2. Kepada Peneliti Selanjutnya

Peneliti selanjutnya lebih mengembangkan penelitian tentang terapi aktivitas kelompok penyaluran energi senam pocopoco dengan melakukan random atau acak pada sampel penelitian dan mempergunakan kelompok kontrol untuk membandingkan hasil penelitian dengan kelompok perlakuan.

\section{KEPUSTAKAAN}

1. Ekawati Gusti Ayu. 2013. Pengaruh Terapi Musik Klasik Terhadap Perubahan Gejala Perilaku Kekerasan Pada Klien Skizoprenia di ruang Kunti RSJ Provinsi Bali. Skripsi Program Diploma IV Keperawatan Poltekes Denpasar.

2. Yosep, I. 2016. Keperawatan jiwa.Bandung: PT Refika Aditama.

3. DepKes RI. 2013. Riset Kesehatan Dasar 2013. Jakarta :Badan Penelitian dan Pengembangan Kesehatan Kementrian Kesehatan RI.

4. Videbeck. 2015. Buku Ajar Keperawatan Jiwa. Jakarta : EGC

5. Direja. 2015. Buku Ajar Asuhan Keperawatan Jiwa, Yogyakarta: Nuha Medika.

6. Keliat. B.A. 2015. Peran serta Keluarga dalam Perawatan Klien Gangguan Jiwa. Jakarta. EGC.

7. Elita. 2013. Persepsi Perawat Tentang Perilaku Kekerasan Yang Dilakukan Pasien di Ruang Rawat Inap Jiwa Rumah Sakit Jiwa Tampan Provinsi Riau. Jurnal Ners Indonesia. Vol . 1, No. 2, Maret 2013.

8. Fausiah dan Widury. 2015. Psikologi Abnormal Klinis Dewasa. Jakarta : UIPress.

9. Sujono. 2009. Asuhan Keperawatan Jiwa. Jakarta : EGC.

10. Heryati. 2015.Patologi Untuk Mahasiswa Keperawatan. Jakarta: Trans Info Media. 
11. Herawati. 2014.Kebugaran Jasmani. Yogyakarta: Universitas Negri Yogyakarta.

12. Kuntaraf. 2015. Olahraga Sumber Kesehatan. Bandung: Indonesia Publishing House.

13. Gani. 2013.Senam Kesehatan :Aplikasi Senam Untuk Kesehatan. Yogyakarta: Mulia Merdeka.

14. Rekam Medik RSJ Provinsi Bali. 2017.Laporan Tahunan Rumah Sakit Jiwa Propinsi Bali. Bangli: Rumah Sakit Jiwa Provinsi Bali.

15. Sodikin dkk. 2015. Pengaruh Latihan Asertif Dalam Memperpendek Fase Intensif dan Menurunkan Gejala Perilaku Kekerasandi Ruang Intensive Psychiatric Care Unit (IPCU) RSJ. Dr. Radjiman Wediodiningrat Lawang. Jurnal Ilmu Keperawatan. Vol: 3, No. 2, November 2015.

16. Kirana. 2014. Efektivitas Senam Aerobic Low Impact Terhadap Aggression Self-Control Pada Pasien DenganResiko Perilaku Kekerasan di RSJ Tampan Provinsi Riau. Jurnal JOM PSIK Vol.1 No.2 Oktober 2014.

17. Karim. F. 2014.Panduan Kesehatan Olahraga Bagi Petugas Kesehatan. Jakarta:Departemen Kesehatan

18. Lilik. 2011. Aplikasi Praktik Klinik. Yogyakarta: Graha Ilmu.

19. Akhmad,H. Handoyo, setiono, T. Pengaruh Terapi Senam Aerobic Low Impact Terhadap Skor Agression Self-Control Pada Pasien Dengan Risiko Perilaku Kekerasan di ruang Sakura RSUD Banyumas. Jurnal Ilmiah Kesehatan Keperawatan Vol 7 No.3 (2011) .

20. Purniasari. 2013. Pengaruh Terapi Musik Relaksasi Rindik Terhadap Kemampuan Mengontrol Perilaku Kekerasan Pada Klien Skizofrenia di Rumah Sakit Jiwa Provinsi Bali. Skripsi Stikes Wiramedika PPNI Bali.

21. Jayanti.,Tirtayasa.,Sutjana.,aDiatmi ka.,Adiputra.,Handari.2017.senam zumba meningkatkan daya tahan kardiovaskular dan kesehatan mental pada subjek dengan skizofrenia di RSJ Provinsi Bali. Sport and fitness Journal. Volume 5 No.3.2017.ISSN2302-688x 